\title{
City structure - the phenomenon of exclusion of space
}

\author{
Marta Szejnfeld ${ }^{1}$, Grzegorz Kmiecik², Hanna Szymczak ${ }^{2}$
}

\begin{abstract}
A special feature of spaces with urban character is the phenomenon of exclusion, which refers both to the space and the community, causing deformation and the disappearance of the unity of the urban structure as a whole. Spatial segregation processes - resulting from social polarization - causes low-income or marginalized groups lack of access to a high-quality urban space. Excluded spaces have become a constant component of visual reality in which gated communities, guarded buildings, or corporation complexes have divided the urban fabric, and in opposition to the city, are capturing more and more spaces.

The result of the appearance of the excluded spaces is the lack of the right to the city for all its inhabitants. Foresaid lack deprives the participant of the possibility of observation and penetration the urban structure, which further deepens the sense of alienation. In such spatial conditions the longing for re-evoking the idea of a sustainable city is born. The essence is therefore an insightful diagnosis of the impact of uncontrolled processes shaping the urban structure deepening segregation and exclusion from the urban space.
\end{abstract}

Keywords: urban transformation, exclusion, inhabitants

\section{Introduction}

The phenomenon of exclusion of space is defined as spatial segregation processes resulting from social polarization. The impact of uncontrolled processes deepens the segregation and exclusion from the urban space.

Spatial exclusion distinguishes itself with the lack of clear physical borders with simultaneous strong psychological boundary in the form of fear of that very space. What follows up is a physical dissolution visible in space in the shape of an increasingly deteriorating condition of buildings and infrastructure, an excess of eyesore and the feeling of greyness. Spatial exclusion as a result of complex disintegration of urban space deprives humans of the possibility of relocation and 'escaping'. Social disintegration is manifested in the lack of identification with space, the disappearance of social bonds and identity. This space gets forgotten by the 'others' and drifts to be forgotten by its own inhabitants. The question which derives from these conditions is: who is the city for?

The urban environment can be perceived as a system of elements relevant for its users and its cognition is impossible without the knowledge of the users (Bańka, 2002). The impact of area obviously affects the lives and the development of the humans. Thus, the exclusion means the inability of unit identification both with respect to other members of the community as well as to the space.

$\mid{ }^{1} \mathrm{PhD}$ candidate of the Warsaw University of Technology, Faculty of Architecture, Assistant at the Institute of Urban Planning and Architecture, Poznan University of Life Sciences, Poland.

2 Assistant at the Institute of Urban Planning and Architecture, Poznan University of Life Sciences, Poland. 
Wright created the idea of urbanity as a way of social life, which in most everyday contacts, interpersonal in modern cities, is impersonal. Today, the city is not only a part of society in general, but an expression of the nature of a larger social system and the factors of shaping the system (Giddens, 2012). The very definition evolves in social consciousness, not as a physical space, but as a kind of symbol or character of recording of the urban space. The space undergoes very deep transformations, requiring its new definition. The new definition focuses on the dematerialization of the concept, where the social networking opportunities are independent of the form of the space by finding its place in virtual space. Spaces excluded are the areas not created by any community. Such sites are devoid of identification and identity. Erosion of space, its gradual though visible atrophy and deformation, as elementary urban structures is a fundamental threat to the development of modern cities.

The exclusion is seen today as a social phenomenon contributing to the alienation between individuals. On the other hand, it shows from behind the scenes the play roles in the community of the modern city. Life in the big city deprives people of a sense of personal identity and uniqueness.

The exclusion has several dimensions. The first dimension relates to an individual-the individual is excluded if none is not interested in him/her, no one sees them. The next dimension involves social groups which, because of their distinct features (material, cultural, class, racial, etc..) were isolated or isolate themselves. Another dimension includes space (gated communities), which was isolated from the urban tissue or 'no one's spaces', which are characterized by poor social control.

\section{Factors}

\section{Anonymity}

In the era of globalization, the crisis of the modern city is connected with the non uniform expanding into the urban tissue and the development of modern social institutions conducive to the development of modern urban anonymity. It is a highly developed modern society, created through the emergence of once modern institutions, and it is characterized by unprecedented growth and development of tradition, which melts and questions the established order of all customs and traditions (World YOUTH Report). The main consequence of this momentum is the particular interaction or noninteraction at all with people, and the way of functioning in everyday life.

There are some who chose a big city to live in because this specific case is a positive side of the phenomena of the anonymity. It seems that large cities offer anonymity, which, however, turns into a profound alienation and loneliness.

\section{Readability}

Readability of the city structure refers to the basic principles of urban design. Today the process of shaping urban space is far from original ideas and assumptions based on a universal code, understood by all users of the space. Readability of the city, as defined by Kevin Lynch (2011), is the ease with which you can quickly identify a given space, district or larger area, forming a coherent whole at the same time. Today the legibility of the city comes down to the form the virtual map, while real symbols are hidden behind the walls 
of billboards, advertisements and displays. Lack of clarity leads to chaos in the urban space, to the disappearance of the city structure, which loses its shape, spilling out into the suburbs.

\section{Identity}

The anonymity of modern urban structures is an everyday part of our reality, in which everything starts to look like anything. In such an environment, there appears irresistible longing to restore sites that would link to the tradition of 'genius loci'. The question of the identity of the place and its contemporary definition has become a subject of great interest in recent years, both because of the lack of clarity and a certain abstractness of the concept itself. Today, the idea of the identity of the place can be explained on the basis of a metaphor whose meaning changes with the change of context. Every place is a complex system which reveals the relationship between space and the recipient, where the identity is expressed in relation to this space. It exists only when we can open up ourselves and see the values stemming from different contexts - historical, esthetic, and religious. Thanks to human efforts and activity it is possible to reveal the identity of the place. "Essentially the experience of space requires our activity"(Gutowski, 2007). The French architect Jean Nouvel said: "Every time I try to find the missing piece of the puzzle, the right building in the right place", for whom there exists no leading universal style and who defines context in a very broad sense, covering many aspects such as culture, location and function. It is not about the mythological 'magic place' but about the creation of places that are friendly and close to people, places people can identify with.

\section{How the city space may impact on individual's action?}

The impact of the urban environment on life and the way humans behave is indisputable. As an outstanding urban sociologist Robert Park wrote "if the city is the world created by man, it is also a world in which he is forced to live from now on. In this way, indirectly and without full awareness of the essence of his view, by forming the city a man transformed himself too" (Harvey, 2012). Therefore, it is not possible for urban space, the space of the city not to affect relationships and social behavior. Moreover, in an era of increasing urban population or even overcrowding and unbridled growth the impact of urban space is becoming increasingly significant.

Spaces excluded are characterized by the loss of the relationship human-human and human-space. This is accompanied by the loss of identity and anonymity which in turn leads to the fall of the community that is the foundation of the social structure of the city. Exclusion of space is expressed in the physical division of the city into pieces puzzles, which, however, do not represent the whole complex picture of the city. The result is the emergence of new spatial structures as Edge City (Garreau, 1992), metropolises sucking in smaller structures or overwhelming urbanization of rural areas.

\section{Public space}

The key space in the city are public areas, common and available to all by their definition. But in times of ongoing computerization and new technologies, the concept 
of public space begins to function not as a physical agora conceived by Aristotle but is placed in virtual space as a virtual agora.

Public spaces function as a medium of communication in so far as messages are carried through communication in those spaces. They are arguably one of the oldest forms of media. "We are convinced that since each medium of communication leaves its mark upon us by altering our institutions, personal attitudes and values, that this shift from public space to private place and media non-place interactions will likewise alter our attitudes and values, particularly with respect to our sense of civic engagement and communitarianism” (Gumpert, Drucker, 2001).

The decreasing size of the common spaces in the cities, which are the main meeting places and places of relationship with another man contributes to the disappearance of these relationships and the 'fall of public man' (Bauman, 2000).

\section{Types of excluded space}

There are four main types of excluded spaces:

1. Non-places, expressed by shopping malls and their close surroundings, subways, consumption spaces, bus or tramp stops,

2. Out of space, reflected by: illusion space, virtual space or digital space,

3. Hidden space like space not accessible for general view, limited availability space, 'ghetto for the rich',

4. Involution space, that characterize slums, neglected spaces or hot spot spaces.

\subsection{Non-places}

A special feature of modern cities are uncontrolled spatial processes shaping urban structure in incomprehensible and unreadable way, thus deepening the sense of exclusion.

Formed non-place (Augé, 1995), spaces that despite being filled up with people remain unreadable. The increase of spaces serving only the movement of people, such as stations, airports, subway stations or supermarkets, are a continuous transformation of the city and the birth of a new urbanity of kinetic society where space does not count, only the time it takes to cover it. These sites are characterized by uniformity through standardization and homogeneity of space, which does not identify any group with. Such places do not have a relationship with a particular characteristic of urban tissue and can function anywhere. The versatility of these sites deprives them of their authenticity and diversity. The non-places have not anyone's social structures, people are a part of them, but do not affect their shape in any way, playing the role of guests or passers.

Fig.1. Properties of non-places.

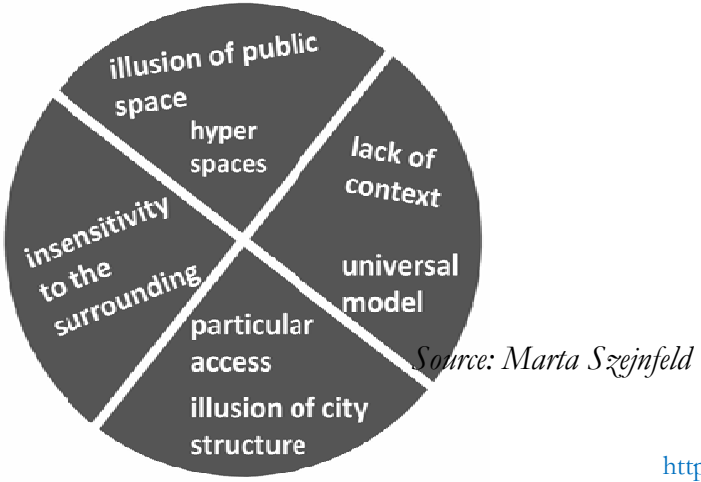


Non-places as real forms influence the perception and reception of space generated in the minds of its users. The method of its formation and its specific nature - hurry and wait at the same time, clearly affects humans. A number of stimuli makes humans not able to read it or they read it without understanding and the additional mass of information in the form of ads, billboards causes distortion.

Non-places have their own specified geometric dimension, defined by the spatial forms. But they lack the history, experience of continuity and identity built by individual factors relating to specific objects or social groups, some cultural code. As the antithesis places however are 'real measure of our times' (Augé, 1995).

E. Relph (1976) claimed that, with mass communication, and increasingly ubiquitous high technology, places become more and more similar, so that locations lose a distinctive 'sense of place'. With increased personal mobility, people are said to identify themselves less with one place; the pull of the home town is slackening. This view is contested; it might be that some meanings are lost as places become increasingly homogenized (similar new architecture, the same chain stores, and so on), but that new meanings are gained (Myhew, 2013).

\subsection{Out of space}

Dematerialization of the space of the city began to be an expressive process where, by breaking down the impression of materiality of buildings, which reflects the surroundings and by means of screens and interactive sensors placed on buildings, the virtual world is entering the reality of cities. In areas traditionally valued as a space of symbolic and historical character of cities, the digital world sneaks into, devoid of the sense of locality and celebrating transnational media hype and the consequent delocation of urban space.

Contemporary urban structure is revolutionized by the technical-information solution where there is a mutual relationship between the flow of physical and virtual structures. The illusion of space refers to the urban space filled with glass buildings where windows reflect both themselves and pedestrians, strollers and passengers of the buses. The space created by the repetition of illusion takes the journey of the viewer-passer confused by the lack of coherence and fragmentation of that space. It seems to say, 'everything is an image' or 'there is no window' - at the same time (Rewers, 2005).

An expression of the creation of such space is the virtuality of the city, which arises as a result of:

- medial extension of the traditional 'polis', which is reflected in the network, such as the ATMs or traffic cameras,

- city completely formed in the electronic space such as displays of cities presented on the Internet, a virtual city created in computer games, in which participants lead a parallel life with a new identity in an unreal city,

dematerialization process of space. 
Fig.2. Properties of out of space.

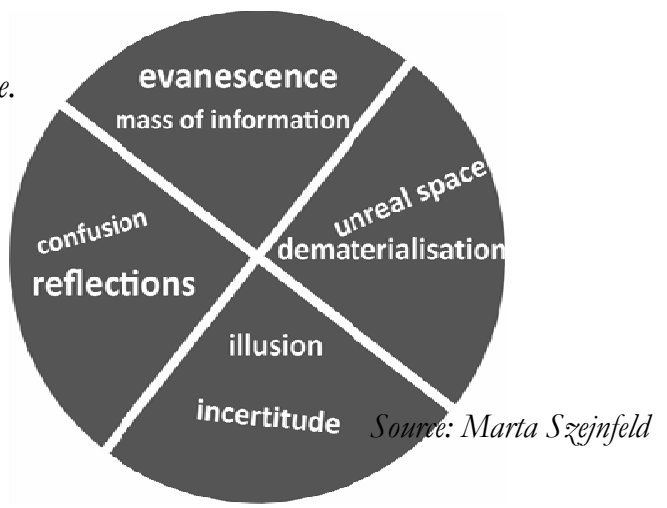

Urban space uses the rhetoric of the mirror, while the TV screen and the threshold of the city becomes the address of the page on the Internet. The technology theorist Paul Virilio, in his definition of space, points out that the limits of the city itself have come into question largely because of the new informational and communication technologies have introduced a novel idea of space - the virtual or dematerialized space. He also describes the relative devaluation of the physical concept of space and place (Poddar, 2008).

\subsection{Hidden space}

Result of urban sprawl is also associated with the more extreme forms of spatial segregation - a growing number of gated communities in the within urban areas and outside. These spaces contribute to the exclusion process understood as spatial exclusion relating to the communities living in isolated districts because of the social statute of their residents, but also to other isolated communities and understood as the exclusion of space that applies to the places which, by virtue of belonging to a certain social group were isolated from the town.

Fig.3. Properties of hidden space.

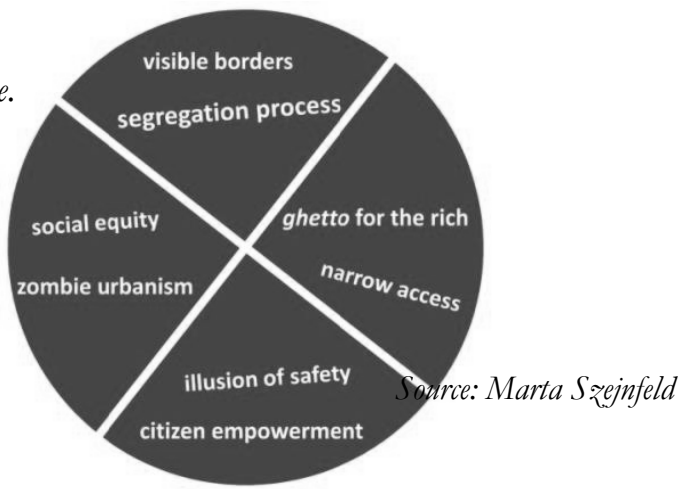

Hidden spaces, as an example of a closed housing, indicate economic and social status of their members. Their rapid development is related to the process of urban gentrification, which is significantly visible in the societies 'working their way up' like in Poland. They result in large areas of urban emptiness in a spatial form - monofunctionality, no life, detachment from the environment, and in social aspects - growing differences in society, lack of social contacts or evoking additional tensions among different social groups. 
Dividing the urban tissue, in opposition to the city absorbs bigger and bigger areas, resulting in loss of the urban structure as a whole.

\subsection{Involution space}

The danger of this phenomenon has been recognized in the report of the European Commission on the future of European cities, where they state: "during the current economic turmoil, in which the financial crisis has already had a serious impact on employment and public budgets, we need to mobilize all forces to limit the negative consequences for the most vulnerable social groups" (EC, 2011).

The physical environment and social environment will be subject to the phenomenon of deepening degradation. The physical environment of space undergoing a slow destruction at the absence of opposition or counteraction against this process leads to the disappearance of ties between the inhabitants of the area, namely, the local community. Neglected space becomes an excluding, alien, space. Residents of such space, if possible, often seek to move to another place (Wilson, Kettling, 1982).

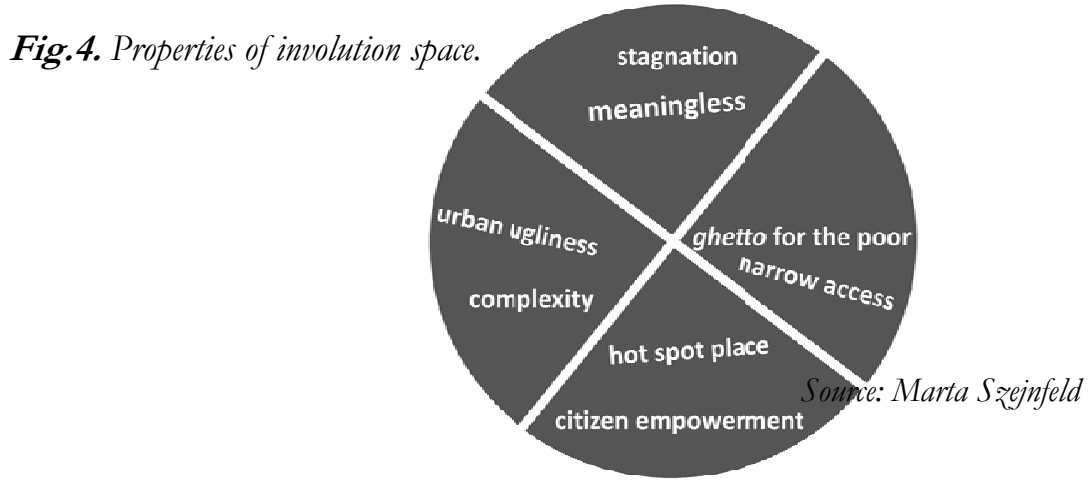

Involution spaces are the result of a complex process of urban decay. This place is shameful and thus not shown. They are formed as in the case of hidden spaces the result of social segregation. What makes them different is the lack of clearly defined physical boundaries in the form of walls, fences but there is a strong psychological border in fear of entry into such space. At the same time the space is excluded from the image of the city in the minds of people who do not reside in it.

The problem of such space is little or no interest of citizens this space does not concern and the municipal authorities who cannot see or do not want to see the problem. Interest appears only from national security and social welfare centers. Involution spaces are closely associated with the concept of the right to the city: 'Who has the right to the city?' As a result of the ongoing process of spatial segregation, low-income groups or marginalized groups do not have access to high-quality public space. A physical spatial environment and a social environment will be a subject to a phenomenon of deepening degradation. The physical environment of a residential space is slowly destructed by the absence of any objections or by lack of counteraction to this process, leading to the disappearance of the ties between inhabitants of the given area thus a local community. Neglected space becomes an alienated, excluded space. Residents of such space often 
seek to move to another location as far as possible. This space is forgotten by strangers and wants to be forgotten by its inhabitants.

\section{New model of city}

Negative effects of spatial segregation are closely related to uncontrollable process of 'spill-over' of cities - exurbanization. The process of deepening exclusion is growing in Europe, and the dynamics of these changes is accelerating.

The compact structure of the settlement structure constitutes an important basis for effective and sustainable utilization of resources. It can be achieved by means of spatial planning and urban development, which, through a thorough control of the availability of building plots and speculative building projects prevents a disordered city development (Leipzig Charter, 2007).

Fig.5. Exurbanization vs Exlusion.

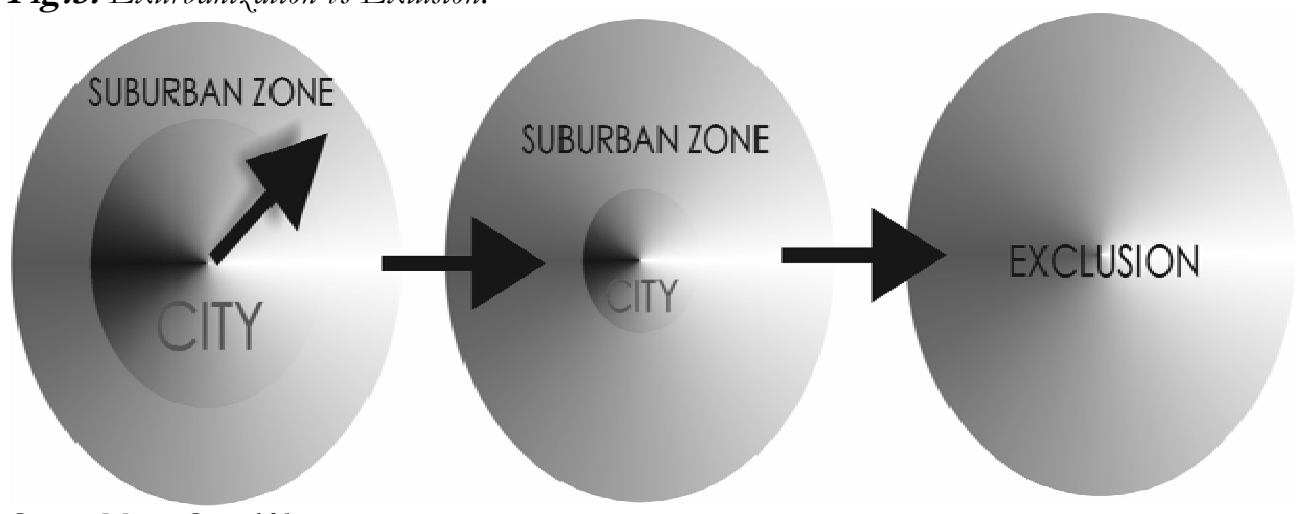

Source: Marta Szejnfeld

Modern society, created by the institutions shaping it, is characterized by unprecedented dynamic growth and the degree of challenging the traditionally established order. According to Anthony Giddens (2012) modern world is running away, not only the pace of change is incomparably weaker than in the case of any prior system, but also their unparalleled range and dramatic effect it has on social practices. The consequence of this rate is the impact on people and their way of functioning in everyday life.

\section{Right to the city}

The feeling of exclusion in the city is closely associated with the concept of the right to the city. Ewa Rewers (2005) writes that the postmodern city belongs no longer only to inhabitants but also to strangers. Strangers are in majority and residents "feel increasingly alienated in their own city, pushed aside - by investors from all over the world, not knowing anything about their existence and not asking about their opinion, by multinational corporations taking out entire districts and reselling them. [...] Who has the right to post-polis?". 
The perception of space is related to the problem described by Hall (2002), which refers to the impact of the density of the spatial structures associated with the uncontrolled growth of urbanization and density of ontogenesis. This means that after a certain level of population density in a particular area, the changes in physiology that manifest themselves in violent and aggressive behavior get intensified. Overcrowding creates situations of inability to maintain ontogenetic dissonance, which is characterized by instability of a balance between being in a group and alone. In too large population centers density in relation to the spatial structure causes the appearance of a series of behavior such as aggression, harassment and withdrawal reactions. They contribute simultaneously to creating the structure of the city, which is closely linked to the notion of exclusion.

Devastated, abandoned and forgotten environment in which it operates in any dimension of the local community, will be a constitutive element of the theory of broken windows.

\section{Summary}

Contemporary urban space is the work of both users and structures. The new concept of localism is no longer associated with a statistically understood area or place. New localism is produced by a stream of - users and structures, consisting of cosmopolitan locations. In the era of globalization, the crisis of the modern city is associated with the expansion of the urban tissue and the development of modern institutions. Spatial and social structure of the city are not isolated places-a new urban form is marked by an unprecedented fragmentation. The fragmentation is based on the increasing isolation and separation of closely related to the segregation according to the criteria of race, class, ethnic, gender, lifestyle, income, etc.. Changes are global, one cannot, therefore, pay no attention to the ever - widening differences, which result in a progressive process of exclusion. Socio-spatial exclusion requires a common strategy based firstly on social integration, especially the near - neighborhood, secondly redefining the importance of public-private space in the city. "Revisiting spatial barriers and promoting accessibility and more spatial freedom can therefore be the way spatial planning can contribute to promoting social integration" (Madanipour, 2011).

\section{References:}

Augé, M. (1995). Non-Places: Introduction to an Anthropology of Supermodernity. London: Verso.

Bańka, A. (2002). Społeczna psychologia środowiskowa. Warszawa: Scholar.

Bauman, Z. (2000). Globalizacja. Warszawa: Państwowy Instytut Wydawniczy.

European Commission, Directorate General for Regional Policy. Cities of tomorrow - Challenges, visions, ways forward. Retrieved June 4, 2013, from web site: http://ec.europa.eu/regional_policy/conferences/citiesoftomorrow/index_en.cfm (accessed 4.06.2013).

European Commission. Leipzig Charter on Sustainable European Cities. Retrieved June 4, 2013, from Web site: http://ec.europa.eu/regional_policy/archive/themes/urban/leipzig_charter.pdf (accessed 4.06.2013).

Garreau, J. (1992). Edge City: Life on the New Frontier. New York: Anchor Books.

Giddens, A. (2012). Socjologia. Warszawa: Wydawnictwo Naukowe PWN. 
Gumpert, G., Drucker, S. (2001). Plato's Cave: Public Space Transformed. Communication Landscapers. New York: Hofstra University.

Gutowski, B. (2007). Wprowadz̨enie. In: B. Gutowski (ed.) Fenomen Genius Loci. Tożsamość miejsca w kontekśsie bistorycznym $i$ wspótczesnym. Papers from a conference held by Muzeum Pałac in Wilanów. Instytut Historii Sztuki Uniwersytetu Kardynała Stefana Wyszyńskiego. Warszawa.

Hall, P. (2002). Cities of Tomorrow: An Intellectual History of Urban Planning and Design in the Twentieth Century. Oxford: Blackwell Publishing.

Harvey, D. (2012). Rebel cities: from the right to the city to the urban revolution. London: Verso Books.

Lynch, K. (1960). The Image of the City. Cambrige: MIT Press.

Madanipour, A. (2011). Social exlusion and space. In: LeGates, R.T., Stout, F. (ed.). The City Reader. Fifth Edition. New York: Routledge.

Mayhew, S. (2014). Placelessness. (n.d.). A Dictionary of Geography. Retrieved June 29, 2014, from Answers.com Web site: http://www.answers.com/topic/placelessness

Poddar, S. (2008). Dematerializing Space: An Interview with Desire Machine Collective by Sandhini Poddar. Discussion of the installation: Trespassers Will Be Prosecuted 2008/10. Princeton.

Relph, E. (1976). Place and Placelessness. London: Pion.

Rewers, E. (2005). Post-polis. Wstęp do filozofii i ponowoczesnego miasta. Kraków: Universitat.

Wilson, J. Q., Ketling, G. L. (1982). Broken Windows. The police and neighborhood safety. The Atlantic Monthly. Harvard.

World YOUTH Report. (2003). Young People in a Globalizing World. United Nations. 